\title{
Pemberdayaan Pemuda Karang Taruna Guna Pemasaran Susu Sapi Segar Di Desa Murukan
}

\author{
Yuniep Mujati Suaidah \\ STIE PGRI Dewantara Jombang
}

Koespondensi: yuniepmujatis@gmail.com

Diserahkan: 18 Mei 2018, Direvisi: 25 Juni 2018, Diterima: 13 Juli 2018

\begin{abstract}
The dedication of the joint authors of the team is located in Murukan Village, Mojoagung District, Jombang. This service is in the form of training and mentoring for the Karang Taruna youth group for marketing cow's milk. Mentoring activities take place for approximately 1 (one) month including training and mentoring in the field of online and offline marketing and business financial recording training. From the results of the dedication, it was known that the participants, namely the youth group of young people have been able to sell their products in various flavors, packaged in cup packaging and marketed online and offline. From the activities that have been carried out by the writer and team, it is expected that it will continue and more incentive development is carried out by the local village government in collaboration with the Jombang Regency government which specifically handles Micro, Small and Medium Enterprises (UMKM)
\end{abstract}

Keywords: Empowerment, cow milk, youth

\begin{abstract}
abstrak
Pengabdian yang dilakukan penulis bersama tim berlokasi di Desa Murukan Kecamatan Mojoagung, Jombang. Pengabdian ini berupa pelatihan dan pendampingan kelompok pemuda Karang Taruna untuk pemasaran susu sapi. Kegiatan pendampingan berlangsung selama kurang lebih 1 (satu) bulan meliputi pelatihan dan pendampingan di bidang pemasaran secara daring dan luring serta pelatihan pencatatan keuangan usaha. Dari hasil pengabdian diketahui bahwa peserta yaitu kelompok pemuda karang taruna telah mampu menjual produknya dengan berbagai varian rasa, dikemas dalam kemasan cup dan dipasarkan secara daring dan luring. Dari kegiatan yang telah dilakukan penulis dan tim, diharapkan akan terus dilanjutkan serta dilakukan pembinaan secara lebih insentif oleh pemerintah desa setempat dengan bekerja sama dengan pemerintah Kabupaten Jombang yang secara khusus menangani Usaha Mikro, Kecil dan Menengah (UMKM)

Kata Kunci: Pemberdayaan, susu sapi, karang taruna
\end{abstract}

\section{A. PENDAHULUAN}

\section{Latar Belakang}

Memasuki era revolusi industry ke 4.0 pemerintah melalui berbagai instansi terkait, terus melakukan pembinaan dan penguatan pada sektor salah satunya pada usaha ekonomi kerakyatan yang berbasis Usaha Mikro Kecil dan Menengah (UMKM) agar tidak kalah bersaing dengan usaha yang lebih besar dan mengandalkan teknologi tinggi. Pemerintah bisa bekerjasama dengan berbagai kelompok masyarakat salah satunya dengan mengoptimalkan peran perguruan tinggi setempat.

STIE PGRI Dewantara Jombang sebagai salah satu perguruan tinggi terkemuka di Jombang merasa terpanggil untuk ikut serta melakukan pelatihan dan pendampingan berbagai jenis usaha ekonomi kerakyatan di Kabupaten Jombang. Berbagai pelatihan dan pendampingan kepada kelompok usaha ekonomi mikro dan kecil yang dilakukan para dosen di STIE PGRI Dewantara Jombang, terbukti telah memberikan perubahan sikap, cara pikir hingga kemampuan mengelola usaha (Purwanto, N., \& Rofiah, C, (2017); Rohim, A., \& Kurniawan, I. (2017).). Dengan pembinaan UMKM di masyarakat akan menumbuhkan kelompok masyarakat yang berdaya dan menyokong 
ketahanan pangan (Purwaningsih, Y,2008). Pemberdayaan kelompok masyarakat peternak sapi perah juga diharapkan bisa memenuhi kebutuhan masyarakat akan susu sehingga tidak terpaku pada impor yang selama ini masih dilakukan Indonesia. Dengan potensi susu yang dimiliki, apabila ditangani dengan serius oleh berbagai pihak, diharapkan menjadi penyumbang devisa negara, pemberdayaan kesempatan bekerja bagi masyarakat, serta berbagai manfaat lainnya (Matondang, R. H., Talib, C., \& Herawati, T, 2012). Hal ini sesuai dengan salah satu unsur Tri Dharma Perguruan Tinggi yaitu pengabdian kepada masyarakat.

Dari berbagai pengalaman pendampingan pengelolaan usaha mikro yang dimiliki STIE PGRI Dewantara Jombang, penulis bermaksud untuk melakukan pelatihan pada kelompok pemuda Karang Taruna di Desa Murukan Kecamatan Mojoagung Jombang. Desa Murukan yang merupakan desa penghasil susu sapi segar di kecamatan Mojoagung. Selama ini para peternak sapi menjual susu sapi dalam bentuk susu segar dengan harga Rp. 9.000,00/liter. Dengan jumlah susu segar yang melimpah di Desa Murukan, penulis bermaksud untuk melakukan pelatihan dan pendampingan untuk pengolahan dan pemasaran susu segar guna meningkatkan nilai jual produk susu sapi segar, yang berujung pada peningkatan pendapatan keluarga.

\section{Profil Mitra}

Kegiatan Pelatihan dan Pendampingan yang dilakukan di Desa Murukan ini melibatkan kelompok Pemuda Karang Taruna setempat. Kelompok pemuda ini dipilih karena dianggap bisa menerima perubahan dan mudah untuk diajarkan sistem pemasaran berbasis daring (online). Selain itu, menurut pengamatan awal penulis, kelompok Pemuda Karang Taruna ini telah memiliki calon konsumen potensial sehingga memungkinkan untuk memberdayakan kelompok Pemuda KarangTaruna ini sekaligus sebagai perintisa dan contoh bagi para peternak sapi perah untuk menjual produk susu segar olahan.

Desa Murukan adalah sebuah desa yang terletak di sebelah timur kecamatan Trowulan. Dimana sebagian besar masyarakatnya menjual susu sapi dan wirausaha rongsokan, dan inilah yang menjadi ciri khas tersendiri dari desa Murukan. Desa Murukan dapat di tempuh 30 menit dari ibu kota Kabupaten Jombang. Desa Murukan terbagi atas 3 dusun yaitu Mulangagung, Murukan Utara, dan Murukan Selatan. Wilayah desa Murukan memiliki luas 194,0000 Ha yang 70,0000 merupakan luas persawahan sedangkan luas wilayah untuk pemukiman hanya memakai 14,5000 Ha dan sisanya merupakan pekarangan, fasilitas umum, tanah rawa dan lain-lain.

\section{B. TINJAUAN PUSTAKA}

\section{Pengertian Karang Taruna}

Sesuai Pedoman Dasar Karang Taruna, pengertian Karang Taruna adalah Organisasi Sosial wadah pengembangan generasi muda yang tumbuh dan berkembang atas dasar kesadaran dan tanggung jawab sosial dari, oleh, dan untuk masyarakat terutama generasi muda di wilayah desa/kelurahan atau komunitas adat sederajat dan terutama bergerak dibidang usaha kesejahteraan sosial. Pembinaan Karang Taruna diatur dalam Permensos 83/HUK/2005 tentang Pedoman Dasar Karang Taruna. 


\section{Tujuan Karang Taruna}

Tujuan Karang Taruna adalah :

a. Terwujudnya pertumbuhan dan perkembangan kesadaran dan tanggung jawab sosial setiap generasi muda warga Karang Taruna dalam mencegah, menagkal, menanggulangi dan mengantisipasi berbagai masalah sosial.

b. Terbentuknya jiwa dan semangat kejuangan generasi muda warga Karang Taruna yang Trampil dan berkepribadian serta berpengetahuan.

c. Tumbuhnya potensi dan kemampuan generasi muda dalam rangka mengembangkan keberdayaan warga Karang Taruna.

d. Termotivasinya setiap generasi muda warga Karang Taruna untuk mampu menjalin toleransi dan menjadi perekat persatuan dalam keberagaman kehidupan bermasyarakat, berbangsa dan bernegara.

e. Terjalinnya kerjasama antara generasi muda warga Karang Taruna dalam rangka mewujudkan taraf kesejahteraan sosial bagi masyarakat.

f. Terwujudnya Kesejahteraan Sosial yang semakin meningkat bagi generasi muda di desa/kelurahan atau komunitas adat sederajat yang memungkinkan pelaksanaan fungsi sosialnya sebagai manusia pembangunan yang mampu mengatasi masalah kesejahteraan sosial dilingkungannya.

g. Terwujudnya pembangunan kesejahteraan sosial generasi muda di desa/kelurahan atau komunitas adat sederajat yang dilaksanakan secara komprehensif, terpadu dan terarah serta berkesinambungan oleh Karang Taruna bersama pemerintah dan komponen masyarakat lainnya.

\section{Tugas dan Fungsi Karang Taruna}

Setiap Karang Taruna mempunyai tugas pokok secara bersama-sama dengan Pemerintah dan komponen masyarakat lainnya untuk menanggulangi berbagai masalah kesejahteraan social terutama yang dihadapi generasi muda, baik yang bersifat preventif, rehabilitatif maupun pengembangan potensi generasi muda di lingkungannya. Setiap Karang Taruna melaksanakan fungsi :

a. Penyelenggara Usaha Kesejahteraan Sosial.

b. Penyelenggara Pendidikan dan Pelatihan bagi masyarakat.

c. Penyelenggara pemberdayaan masyarakat terutama generasi muda dilingkunggannya secara komprehensif, terpadu dan terarah serta berkesinambungan.

d. Penyelenggara kegiatan pengembangan jiwa kewirausahaan bagi generasi muda di lingkungannya.

e. Penanaman pengertian, memupuk dan meningkatkan kesadaran tanggung jawab sosial generasi muda.

f. Penumbuhan dan pengembangan semangat kebersamaan, jiwa kekeluargaan, kesetiakawanan sosial dan memperkuat nilai-nilai kearifan dalam bingkai Negara Kesatuan Republik Indonesia.

g. Pemupukan kreatifitas generasi muda untuk dapat mengembangkan tanggung jawab sosial yang bersifat rekreatif, kreatif, edukatif, ekonomis produktif dan kegiatan praktis lainnya dengan mendayagunakan segala sumber dan potensi kesejahteraan sosial di lingkungannya secara swadaya.

h. Penyelenggara rujukan, pendampingan, dan advokasi social bagi penyandang masalah kesejahteraan sosial. 
i. Penguatan sistem jaringan komunikasi, kerjasama, informasi dan kemitraan dengan berbagai sektor lainnya.

j. Penyelenggara usaha-usaha pencegahan permasalahan sosial yang aktual.

\section{Pengolahan Susu Sapi}

Sebagai desa penghasil susu sapi segar, Desa Murukan memiliki jumlah peternak sapi yang banyak. Namun demikian, para peternak sapi hanya menjual produknya berupa susu segar biasa tanpa ada inovasi lebih lanjut. Padahal ada banyak produk olahan makanan dan minuman yang bisa dikembangkan dengan bahan dasar susu sapi, sehingga meningkatkan nilai jual produk.

Penulis dengan dibantu para mahasiswa, mengajak para pemuda Karang Taruna untuk mengolah susu segar menjadi kemasan susu siap minum dalam cup dengan berbagai varian rasa dan harga terjangkau. Susu diolah secara higienis dengan alat pengolah susu yang dimiliki desa Murukan. Selanjutnya, kemasan yang telah siap dipasarkan secara daring dan luring. Anggota Karang Taruna juga diajari cara pemasaran secara daring dengan menggunakan media Instagram dan facebook.

\section{PELAKSANAAN DAN HASIL KEGIATAN}

Kegiatan yang dilakukan penulis berlangsung selama kurang lebih 1 (satu) bulan selama bulan Februari 2018. Kegiatan ini juga melibatkan mahasiswa STIE PGRI Dewantara Jombang sebagai pendamping di lapangan.

Adapaun kegiatan selama bulan Februari 2018 adalah:

\section{Tahap I : Sosialisasi}

Kegiatan ini berupa sosialiasi dari rencana kegiatan yang akan dilakukan di Desa Murukan. Penulis beserta tim melakukan kunjungan ke pihak pemerintah desa setempat sekaligus melakukan survey awal kondisi peternak / penghasil susu sapi segar dan para pemuda Karang Taruna di Desa Murukan. Kegiatan ini dilakukan di minggu awal bulan Februari 2018.

\section{Tahap II: Pelatihan dan Pendampingan}

Setelah penulis dan tim melakukan survey awal, tim mengadakan pertemuan lanjutan dengan para pemuda karang taruna. Para anggota karang taruna diberikan materi pelatihan pembukuan sederhana untuk usaha dagang susu segar dengan menggunakan software Akuntansi UMKM WinFill versi 3.0. Para anggota Karang Taruna sangat antusias mengkuti kegiatan ini dan tingkat penyerapan materi hingga 80 $\%$. Pelatihan pembukuan sederhana juga perlu diberikan karena bisa membuka wawasan peserta tentang pentingnya pencatatan keuangan usaha yang terpisah dengan keuangan keluarga (Mutiarni, R., Utomo, L. P., \& Zuhroh, S, 2017).

Selain materi pembukuan sederhana, peserta/mitra juga diberikan materi pelatihan tentang pengolahan produk dalam berbagai varian rasa dan pengemasan dalam cup sehingga harga terjangkau oleh konsumen.

Untuk strategi pemasaran, mitra diajarkan untuk pemasaran secara daring dan luring. Untuk pemasaran daring menggunakan media Instagram dan Facebook dan untuk pemasaran luring, peserta diajak untuk melakukan penjualan langsung pada acara car free day di sekitar jalan raya Mojoagung - Mojokerto. Kegiatan ini berlangsung selama 2 (dua) minggu yaitu pada minggu kedua dan ketiga bulan Pebruari 2018

\section{Tahap III: Evaluasi}

Setelah seluruh materi pelatihan disampaikan, selanjutnya tim melakukan evaluasi selama kegiatan di lapangan. Dari hasil evaluasi diketahui bahwa: 
a. Peserta sudah bisa memasarkan produknya secara daring, melalui instagram

b. Degan mengolah produk menjadi berbagai varian rasa, penjualan susu segar mengalami peningkatan. Selain itu, dengan pengemasan produk dalam cup yang siap minum, pendapatan peserta menjadi meningkat. Jika sebelumnya dengan menjual susu sapi segar murni pedagang mendapat keuntungan Rp. 1000,00/liter (Pembelian dari peternak $\mathrm{Rp} \mathrm{8000,00/liter} \mathrm{dijualdengan} \mathrm{harga} \mathrm{Rp.} \mathrm{9.000,00/liter)} \mathrm{tapi} \mathrm{dengan}$ mengolahnya menjadi berbagai varian rasa dan mengemasnya dalam cup ukuran $150 \mathrm{ml}$, pedagang/mitra mendapat keuntungan hingga Rp. 8000,00/liter.

c. Peserta/mitra juga sudah bisa melakukan pembukuan secara sederhana guna mengetahui keadaan keuangan usaha

Namun, dari hasil evaluasi juga ditemukan berbagai permasalahan yang dihadapi mitra, antara lain:

a. Produksi olahan susu sapi masih terbatas pada produk minuman. Untuk mengolah menjadi produk lain seperti yogurt, diperlukan peralatan guna menjaga kesterilan produk. Demikian juga untuk produk olahan yang lain seperti permen susu dan pudding yang tahan lama, diperlukan perlatan yang menjamin higienitas produk. Ini yang menjadi kendala peserta.

b. Masih diperlukan kegiatan pendampingan hingga minimal 1 tahun agar usaha yang dirintis penulis bersama tim bisa tetap berjalan dan terkontrol. Sehingga apabila peserta mengalami kendala dilapangan, bisa dikonsultasikan dengan tim pendamping. Karena itu, pemerintah desa setempat hendaknya menjalin komunikasi dengan dinas koperasi dan UMK Jombang guna pendampinga dan pembinaan selanjutnya.

\section{E. PENUTUP}

Setelah melakukan kegiatan pelatihan dan pendampingan selama kurang lebih 1 (satu) bulan, dapat disimpulkan bahwa kegiatan ini telah berjalan dengan hasil akhir sesuai yang diharapkan. Peserta/mitra telah mampu memasarkan produk susu segar dengan berbagai varian rasa dan kemasan modern sehingga mampu meningkatkan pendapatan.

Kegiatan ini diharapkan tidak berhenti hanya sampai disini. Diharapkan, masih ada upaya pelatihan dan pendampingan untuk produk olahan berbahan dasar susu, mengingat potensi yang ada di Desa Murukan masih sangat besar dan belum tergarap secara maksimal. Untuk itu, pemerintah melalui Dinas Koperasi dan UMK diharapkan mampu melanjutkan kegiatan yang sudah dimulai oleh tim penulis.

\section{DAFTAR PUSTAKA}

Matondang, R. H., Talib, C., \& Herawati, T. (2012). Prospek pengembangan sapi perah di luar pulaujawamendukung swasembada susu di indonesia. Wartazoa, 22, 161168.

Mutiarni, R., Utomo, L. P., \& Zuhroh, S. (2017). Pendampingan Pencatatan Transaksi Keuangan Pada Koperasi Bunga Harapan Desa Ceweng. Comvice: Journal Of Community Service, 1(1), 33-38. 
Purwanto, N., \& Rofiah, C. (2017). Pemberdayaan Usaha Ekonomi Produktif Bagi Masyarakat Di Kecamatan Ploso Kabupaten Jombang. Comvice: Journal Of Community Service, 1(1), 29-32.

Purwaningsih, Y. (2008). Ketahanan pangan: situasi, permasalahan, kebijakan, dan pemberdayaan masyarakat. Jurnal Ekonomi Pembangunan: Kajian Masalah Ekonomi dan Pembangunan, 9(1), 1-27.

Permensos 77 Tahun 2010 tentang Pedoman Dasar Karang Taruna

Rohim, A., \& Kurniawan, I. (2017). Manajemen Usaha Dan Produksi Pada Usaha Mikro, Kecil Dan Menengah (UMKM) Di Desa Carang Wulung Wonosalam. Comvice: Journal Of Community Service, 1(1), 23-28. 